OPEN ACCESS

Edited by:

Jan Petrášek,

Charles University, Czech Republic

Reviewed by:

Lorenzo Frigerio,

University of Warwick, UK John E. Fowler,

Oregon State University, USA

*Correspondence:

Patrick J. Hussey,

School of Biological and Biomedical Science, Durham University, South Road, Durham DH1 3LE, UK p.j.hussey@durham.ac.uk

Specialty section: This article was submitted to Plant Cell Biology,

a section of the journal Frontiers in Plant Science

Received: 27 January 2015 Accepted: 25 May 2015

Published: 09 June 2015

Citation:

Wang P and Hussey PJ (2015)

Interactions between plant endomembrane systems and the actin cytoskeleton.

Front. Plant Sci. 6:422. doi: $10.3389 /$ fpls.2015.00422

\section{Interactions between plant endomembrane systems and the actin cytoskeleton}

\author{
Pengwei Wang and Patrick J. Hussey* \\ School of Biological and Biomedical Science, Durham University, Durham, UK
}

Membrane trafficking, organelle movement, and morphogenesis in plant cells are mainly controlled by the actin cytoskeleton. Not all proteins that regulate the cytoskeleton and membrane dynamics in animal systems have functional homologs in plants, especially for those proteins that form the bridge between the cytoskeleton and membrane; the membrane-actin adaptors. Their nature and function is only just beginning to be elucidated and this field has been greatly enhanced by the recent identification of the NETWORKED (NET) proteins, which act as membrane-actin adaptors. In this review, we will summarize the role of the actin cytoskeleton and its regulatory proteins in their interaction with endomembrane compartments and where they potentially act as platforms for cell signaling and the coordination of other subcellular events. Keywords: actin cytoskeleton, endomembrane system, membrane-cytoskeleton interactions, NET super-family,
Arabidopsis

\section{Introduction}

The actin cytoskeleton is involved in most aspects of plant cell development, cell morphogenesis and establishment and maintenance of cell polarity. It is a dynamic network that is responsive to extracellular and intracellular signals including mechanical stimulation (Hardham et al., 2008) and hormones (Lanza et al., 2012; Li et al., 2014). The endomembrane system is essential for intracellular protein processing, lipid modification and transport, where any dysfunction can affect plant development and signal transduction (Surpin and Raikhel, 2004; Debono et al., 2009; Ding et al., 2012; Boutté and Moreau, 2014). Each of these compartments has to maintain its structural integrity as well as their own chemical and physical properties (such as $\mathrm{pH}$, redox-potential, ion composition), thereby generating a suitable environment for the function of their resident protein components (Jurgens, 2004; Martiniére et al., 2013; Schumacher, 2014).

The interaction between the actin cytoskeleton and the endomembrane system affects various aspects of plant cell function and development (Hussey et al., 2006; Sampathkumar et al., 2013), and remains an area to be more fully explored. Some of the known membrane adaptors proteins do not have homologs in plants (e.g., $\alpha$-actinin and filamin; Hussey et al., 2002). Therefore, plants must have evolved their own protein complexes that localize at the cytoskeleton-membrane interface and mediate any crosstalk between compartments. In this review we focus on proteins that localize at the plant cytoskeleton-membrane interface acting as structural adaptors between the membrane and the cytoskeleton or as platforms that mediate communication between different membrane compartments (Table 1). 
TABLE 1 | Putative actin-membrane adaptor proteins found in plants.

\begin{tabular}{|c|c|c|c|c|}
\hline $\begin{array}{l}\text { Membrane } \\
\text { compartments }\end{array}$ & Proteins & Phenotypes/functions & Notes & Reference \\
\hline \multirow[t]{5}{*}{$\begin{array}{l}\text { Nuclear envelope } \\
\text { (NE) }\end{array}$} & SINEI & Positioning of nuclei in guard cells & $\begin{array}{l}\text { Interact with actin through N-term; NE localization } \\
\text { depends on SUN proteins }\end{array}$ & Zhou et al. (2014) \\
\hline & Formin8 & Cell division and root development & Bundle actin filament in vitro & Xue et al. (2011) \\
\hline & Myosin VIII & $\mathrm{N} / \mathrm{A}$ & Localize to the NE as tail domain deletion mutant & $\begin{array}{l}\text { Golomb et al. (2008), Avisar } \\
\text { et al. (2009) }\end{array}$ \\
\hline & Myosin XI-I & Nuclear shape and movement & $\begin{array}{l}\text { Anchoring to the NE by interacting with } \\
\text { WIT1MIT2 }\end{array}$ & Tamura et al. (2013) \\
\hline & NET3A & $\mathrm{N} / \mathrm{A}$ & $\begin{array}{l}\text { Localize to the NE, and interact with actin through } \\
\text { N-term }\end{array}$ & $\begin{array}{l}\text { Deeks et al. (2012), Hawkins } \\
\text { et al. (2014) }\end{array}$ \\
\hline \multirow[t]{2}{*}{$\begin{array}{l}\text { Endoplasmic } \\
\text { reticulum (ER) }\end{array}$} & $\begin{array}{l}\text { Myosins (XI-I; XI-2; } \\
\text { XI-C; XI-K, etc.) }\end{array}$ & $\begin{array}{l}\text { Root hair development and cell } \\
\text { expansion }\end{array}$ & $\begin{array}{l}\text { Affect the dynamics and structure of ER/actin. } \\
\mathrm{XI}-\mathrm{K} \text { is also enriched in ER microsome }\end{array}$ & $\begin{array}{l}\text { Peremyslov et al. (2010), Ueda } \\
\text { et al. (2010) }\end{array}$ \\
\hline & NAP1 & Trichome development & Form ER associated punctae & Zhang et al. (2013a) \\
\hline \multirow[t]{2}{*}{ Golgi/ER interface } & SPIKE1 & $\begin{array}{l}\text { Cytoskeleton organization, cell } \\
\text { morphology }\end{array}$ & $\begin{array}{l}\text { Co-localize with ERES marker, affect ER } \\
\text { morphology }\end{array}$ & Zhang et al. (2010) \\
\hline & $\mathrm{CP}$ & Hypocotyl and root development & $\begin{array}{l}\text { Localize at the cis-Golgi, activity negatively } \\
\text { regulated by phosphatidie acid }\end{array}$ & $\begin{array}{l}\text { Li et al. (2012), Jimenez-Lopez } \\
\text { et al. (2014) }\end{array}$ \\
\hline Vacuole & NET4A & $\mathrm{N} / \mathrm{A}$ & Localized around tonoplast in root meristem cells & Deeks et al. (2012) \\
\hline \multirow{5}{*}{$\begin{array}{l}\text { Plasma } \\
\text { membrane (PM) }\end{array}$} & BRK1 and Scarl & Trichome development & Enriched in cell border and corner & Dyachok et al. (2008) \\
\hline & Myosins (VIII) & $N / A$ & $N / A$ & Golomb et al. (2008) \\
\hline & $\begin{array}{l}\text { Formins (FHI, 4, 5, } \\
\text { 8) }\end{array}$ & $\begin{array}{l}\text { Root hair development }(\mathrm{FH} 4,8) \text {, } \\
\text { pollen tube and polarized cell } \\
\text { growth }(\mathrm{FH} 1,5)\end{array}$ & $\begin{array}{l}\text { Capable for both actin and microtubule } \\
\text { interaction. }\end{array}$ & $\begin{array}{l}\text { Cheung et al. (2010), Deeks } \\
\text { et al. (2010), Van Gisbergen } \\
\text { et al. (2012), Martiniére et al. } \\
\text { (2011) }\end{array}$ \\
\hline & PLD & Cytoskeleton organization & Interact with actin, microtubules and MAP65 & $\begin{array}{l}\text { Pleskot et al. (2010), Zhang } \\
\text { et al. (2012) }\end{array}$ \\
\hline & NET2A & $\mathrm{N} / \mathrm{A}$ & $\begin{array}{l}\text { May form signaling complex with protein kinase at } \\
\text { the PM of pollen tube }\end{array}$ & $\begin{array}{l}\text { Skirpan et al. (2006), Deeks } \\
\text { et al. (2012) }\end{array}$ \\
\hline $\begin{array}{l}\text { ER/PM contact } \\
\text { sites }\end{array}$ & VAP27 and NET3C & Pollen and embryo development & $\begin{array}{l}\text { NET3C/NAP27 in a complex, interact with actin } \\
\text { and microtubules respectively }\end{array}$ & Wang et al. (2014) \\
\hline \multirow[t]{2}{*}{ Plasmodesmata } & Myosin VIII & $\mathrm{N} / \mathrm{A}$ & N/A & Golomb et al. (2008) \\
\hline & NET1A & Root development & NET super-family & Deeks et al. (2012) \\
\hline \multirow[t]{2}{*}{ Chloroplast (Cp) } & CHUPI and KAC & Cp movement and anchorage & $\mathrm{N} / \mathrm{A}$ & $\begin{array}{l}\text { Kadota et al. (2009), Suetsugu } \\
\text { et al. (2010) }\end{array}$ \\
\hline & Myosin XI-F & $\mathrm{Cp}$ and mitochondria arrangement & Localize to the Cp body and stromules & Sattarzadeh et al. (2009) \\
\hline
\end{tabular}

\section{Actin-Nuclear Membrane Interaction}

The nuclear envelope (NE) is a double membrane structure that separates the chromatin and nuclear content from the cytoplasm. It breaks down during mitosis and reassembles around the newly formed sister nuclei (Graumann and Evans, 2011). The outer membrane is continuous with the ER and the inner membrane is in close association with the chromatin through the interaction of inner membrane proteins (Meier, 2007). The SUN (SAD1/UNC84) and KASH (Klarsicht/Anc/Syne-1 homology) domain protein complex is one of the best known examples for the interaction between the NE and the cytoskeleton. Such complexes are present in plants and animals and their organization is similar. The SUN proteins localize at the inner nuclear membrane and interact with KASH domain proteins at the outer membrane, which associate with the cytoskeleton (Graumann et al., 2014). The shape of the nucleus is regulated by both proteins as knockout mutants exhibit a less elongated nuclear membrane structure
(Zhou et al., 2011). SINE1 (SUN-domain Interacting NE protein 1) is the well characterized KASH-like protein in plants. It interacts with $\mathrm{F}$-actin through its $\mathrm{N}$-terminal sequence and also localizes to the NE in guard cells and non-differentiated root cells (Zhou et al., 2014).

Formins are conserved proteins that regulate actin dynamics by functioning at the "barbed end" of the actin filament (Blanchoin and Staiger, 2010). A study on Arabidopsis formin8 demonstrated that this protein induces actin bundling and a population of the endogenous protein was shown to localize to the NE (Xue et al., 2011). Moreover, Myosin XI-I is recruited by interacting with NE proteins, such as WPP domain-interacting proteins (WIPs, also known as putative plant KASH proteins; Tamura et al., 2013). It is required for maintaining the morphology and regulating the movement of the nucleus in root hair cells and in leaf mesophyll cells after dark treatment (Tamura et al., 2013). Movement of nuclei is especially important during fertilization where the vegetative nucleus moves from the pollen grain to the 
tip of pollen tubes. This process is known to be regulated by WIPs and myosin XI-I (Zhou and Meier, 2014).

\section{Actin-Endoplasmic Reticulum Interaction}

The endoplasmic reticulum (ER) is involved in the synthesis, folding and quality control of membrane and luminal proteins destined for secretion, $\mathrm{Ca}^{2+}$ storage, lipid, and auxin biosynthesis (Vitale and Denecke, 1999; Wang et al., 2011; Kriechbaumer et al., 2012). The dynamic property of the ER is mainly regulated by the actin cytoskeleton, which is closely associated with the ER network (Boevink et al., 1998; Sparkes et al., 2011). There is some evidence that microtubules also influence the mobility of the ER, but to a lesser extent or at a much slower rate (Hamada et al., 2014).

Myosin XI isoforms (13 isoforms in Arabidopsis) exhibit differential effects on the inhibition of ER remodeling, and they are the most well studied proteins regulating this process. Myosin XI isoforms have an N-terminal motor domain, a regulatory neck domain and a C-terminal tail domain. Tail domain deletion mutants are commonly used to study the effect of myosin on organelle movement; these proteins could potentially be recruited to the destination membrane but they will have no actin association capacity. The over-expression of such dominant-negative mutants of myosin XI isoforms in tobacco leaf enhance the persistency of ER membrane, as well as altering ER morphology (Sparkes et al., 2009a; Griffing et al., 2014). Myosin XI-K is also found to be enriched in the ER microsomal fractions and localizes to membrane structures along the F-actin (Peremyslov et al., 2012). Its deficiency affects the organization of the ER network and the associated actin filaments (Ueda et al., 2010). Due to the diversity of myosin tail domains, each may localize to multiple membrane compartments and regulate the movement of organelles other than the ER including peroxisomes and mitochondria (Hashimoto et al., 2005; Avisar et al., 2008a; Peremyslov et al., 2008, 2010; Sparkes et al., 2008; Sattarzadeh et al., 2013). However, it is not clear whether the inhibition of their mobility is directly related to less actin cytoskeleton association or a global effect of reduced cytoplasmic or ER streaming.

In mammals, disturbing any ER-microtubule association or removing the microtubule network alters the ER morphology (Vedrenne et al., 2005; Vedrenne and Hauri, 2006). In most plant cells, treatment with a drug that has the net effect of F-actin depolymerization (Latrunculin B) inhibits the movement and remodeling of the ER, but its effect on ER morphology is less significant (Sparkes et al., 2009a). Some in vitro studies on ER microsomes from BY2 cells claim that the formation of the ER network does not require a functional cytoskeleton, as isolated ER microsomes are able to assemble into a polygonal structure. However, this process is significantly inhibited by depletion or over-expression of dominant-negative myosins (Yokota et al., 2011).

\section{Actin-ER/Golgi Interface Interaction}

The Golgi receives secretory vesicles containing proteins and other substances from the ER, to its cis-face and sends the sorted materials to their destinations (Hawes, 2005). Golgi bodies are physically connected to the ER surface in higher plants (Sparkes et al., 2009b); they interact with the ER through a proteinaceous bridge, which contains COPII proteins required for ER exit site (ERES) formation (Hanton et al., 2009). Interactions between microtubules and ERES components have been described in animals and these involve direct interaction with Sec23p (coat protein of COPII vesicles) and the dynactin complex (Watson et al., 2005).

In plants, the actin cytoskeleton substitutes for microtubules as the major cytoskeletal component involved in membrane trafficking, so it is reasonable to speculate that an analogous phenomenon exists where actin associated protein complexes are involved in bridging the links. Indeed, recent studies revealed that the ER network is likely to be one of the main reservoirs for the Scar/Wave signaling complex, and the ARP2/3 complex (Zhang et al., 2013a,b), whose activation promotes actin filament branching and polymerization (Deeks and Hussey, 2005; Uhrig et al., 2007). SPIKE1, a guanine nucleotide exchange factor that acts up-stream of the Scar/Wave complex, is found to be ERES localized. Its depletion changes ER morphology as well as the localization of ERES components (Zhang et al., 2010). In addition, the barbed end actin binding protein, capping protein $(\mathrm{CP})$, has recently been identified as associating with a cis-Golgi marker (Jimenez-Lopez et al., 2014), which raises the possibility that plant ERES are also sites where actin dynamics are regulated.

In animal cells, the interaction between the microtubule cytoskeleton and ERES is required for the movement and formation of the ER-Golgi intermediate compartment (ERGIC), which is essential for the secretory pathway (Appenzeller-Herzog and Hauri, 2006). So, what is the function of actin regulatory proteins (e.g., Scar complexes and $\mathrm{CP}$ ) that localize to the ER/Golgi in plants? In ARP2/3 mutants, Golgi bodies are found to be trapped within dense patches of actin filaments within the distorted trichomes; this phenomenon could possibly result in an altered Golgi mobility (Mathur et al., 2003). Moreover, it is known that plants do not have ERGIC like structures, and it has been debated for decades that Golgi and ER are connected forming a "secretory unit" (Robinson et al., 2015). Disrupting the cytoskeleton has no obvious effect on ER-Golgi trafficking in tobacco cells (Brandizzi et al., 2002; Saint-Jore et al., 2002). Therefore, the function of these actin regulatory proteins in ERGolgi "vesicle trafficking" is an area open to investigation.

\section{Actin-Vacuole Interaction}

Plant vacuoles are sub-divided into two groups: the protein storage vacuoles (PSVs) and the lytic vacuoles (LVs; Hunter et al., 2007; Olbrich et al., 2007). The transition between the two types of vacuole has been observed in root meristematic cells (PSV to LV) and cells at the early embryo stage (LV to PSV; Feeney et al., 2013). The actin network is found at the tonoplast surface where it regulates vacuole structure and dynamics (Higaki et al., 2006; Sheahan et al., 2007). It is expected to play a major role during the process of vacuole transition, where dramatic tonoplast membrane re-organization has been observed. One hypothesis that has been suggested for the formation of the central $\mathrm{LV}$ is by the fusion of multiple small PSVs during development. Actin 
dynamics regulated by actin associated proteins may provide the force that brings PSVs close together, allowing the docking and fusion process to take place. Such processes have been reported in guard cells during stomatal opening (Li et al., 2013), and perhaps this phenomenon could be extrapolated to include other cell types. In addition, actin is also essential for membrane trafficking between the vacuole and the Golgi compartment (Kim et al., 2005).

\section{Actin-Plasma Membrane Interaction}

The plasma membrane (PM) is a main site of association for actin regulatory proteins including subunits of the Scar/Wave complex (Dyachok et al., 2008), myosins (Golomb et al., 2008), profilin (Sun et al., 2013), and formins. Multiple plant formin homologs have been found at the PM of various cell types suggesting an important role in plant cell development and morphogenesis (Cheung and Wu, 2004; Favery et al., 2004; Deeks et al., 2005; Cheung et al., 2010; Martiniére et al., 2011). They can be recruited to the PM through direct transmembrane domain insertion (e.g., AtFH1), interacting with phospholipids (class II formins) or possibly through the indirect association with other proteins (Van Gisbergen et al., 2012; Cvrckova, 2013). Some formins have been found to have unique microtubule binding regions and are therefore capable of interacting with both actin and microtubule filaments (Deeks et al., 2010; Li et al., 2010; Zhang et al., 2011). Another example of an actin/microtubule dual associating protein is Phospholipase D (PLD), which regulates cell signaling by converting structural phospholipids to phosphatidic acid (Pleskot et al., 2010, 2013). Furthermore one study has demonstrated that PLD at the PM can bind the well-known microtubule interacting protein MAP65 in response to salt stress (Zhang et al., 2012). The PM-actin interaction is also essential for the development of stomata, which requires an asymmetrical division of subsidiary cells. Proteins from the SCAR/WAVE complex, as well as the receptor-like kinases PAN1 and PAN2, localize to the PM in a polarized pattern. This complex activates ARP2/3 dependent actin polymerization and drives nuclear movement and cell division (Facette et al., 2015).

\section{Actin-PM/ER Contact Sites and Plasmodesmata Interaction}

Plasmodesmata (PD) are plant specific channels that traverse the cell walls between cells and where the cytoskeleton, PM and ER converge (Fitzgibbon et al., 2010). They are required for cell-tocell communication and transport, such as the movement of viral proteins during viral infection (Avisar et al., 2008b; Tilsner et al., 2013; Amari et al., 2014). Actin filaments and certain myosins have been demonstrated previously to associate with PD. For example, myosin VIII localizes to PD (Radford and White, 1998; Golomb et al., 2008) and some myosin XI isoforms are recruited to the cell plate during cytokinesis where most primary PDs are formed (Reichelt et al., 1999; Yokota et al., 2009). As well as at PD, the ER and PM join at, what are known as, ER/PM contact sites (EPCS). They are found predominantly at the cell cortex (especially in epidermal cells), but they are also likely to be associated with the PD at cell junctions. The NET3C and VAP27 proteins, which interact with the actin and microtubule cytoskeletons respectively, are required for the formation of EPCS in plants (Wang et al., 2014). The function of the cytoskeletonEPCS interaction in plants is not clear, one hypothesis is that such an interaction is important for cargo exchange during endocytic and exocytic trafficking (Pena and Heinlein, 2013).

\section{Actin-Plastid Interaction}

Strictly speaking, chloroplasts are not classified as part of the endomembrane system as they are endosymbionts. But their movement is actin dependent and this movement can be light responsive (Higa et al., 2014), which presents a unique aspect of actin-membrane interaction. For example, the CHloroplast Unusual Positioning 1 (CHUP1) protein localizes to the outer membrane of chloroplasts and is bound to short actin filaments (Kadota et al., 2009). It also interacts with two kinesin-like proteins (KAC1 and $\mathrm{KAC} 2$ ), which mediate this actin-based movement (Suetsugu et al., 2010). Not surprisingly, overexpression of some of the myosin XI tail domain truncations (e.g., myosin XI-F that localize to the chloroplast body and stromules) also has an effect on chloroplast movement (Sattarzadeh et al., 2009).

\section{The NET Super-Family and Conclusion}

Recently, the NET super-family of actin binding proteins has been identified. They interact directly with F-actin through a conserved N-terminal domain, and are recruited to different membrane compartments through a highly variable C-terminal sequence (Figure 1). A few members of the NET family have been

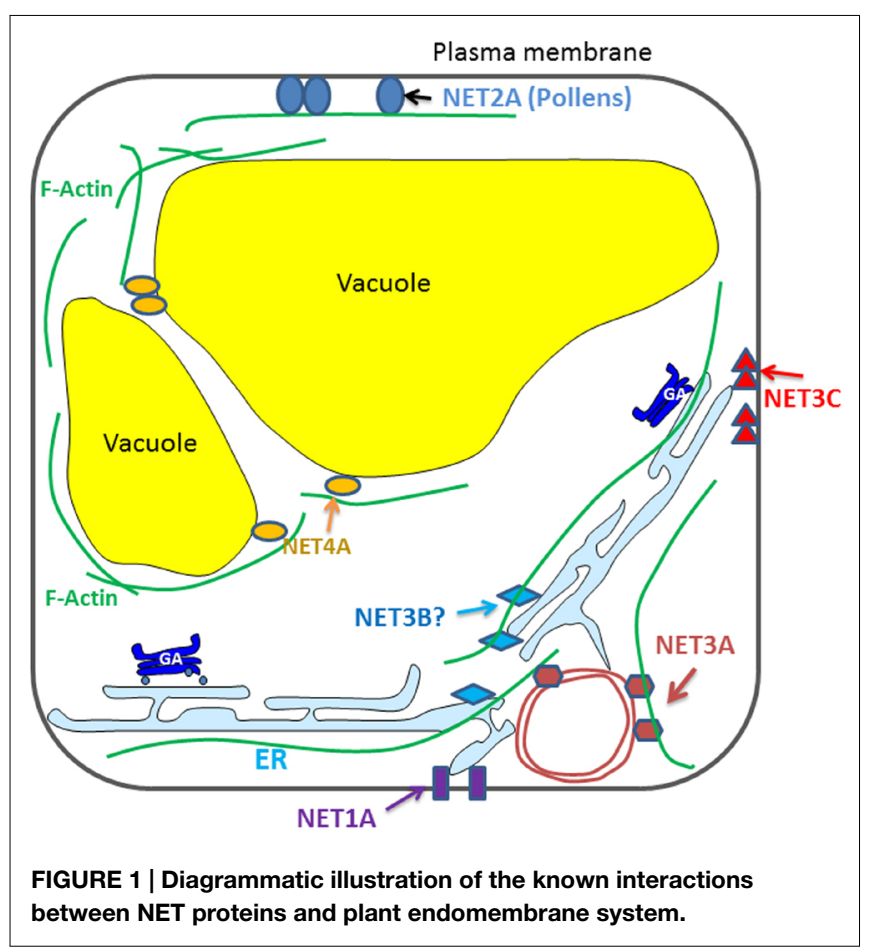


characterized and each of them localize to distinct membrane compartments: the NE, NET3A; EPCS, NET3C; and the tonoplast, NET4A (Deeks et al., 2012; Wang et al., 2014). The mechanism of action of these proteins is only just starting to be evaluated and now represents a key area for developing our understanding of plant cytoskeleton-membrane interactions.

NET1A, the representative member of the NET1 subfamily, is a novel type of PD associated actin-membrane adaptor. Its knock out (along with NET1B) affects root development in that a long root phenotype is observed. However, the mechanism that causes this defect is unclear but it is suggested that the phenotype may be the result of aberrant transport of as yet unknown substances between cells. NET2A is pollen specific and it forms PM associated punctae that co-align with the actin cytoskeleton in pollen tubes (Deeks et al., 2012). The petunia homolog of NET2A forms a complex with PM-integrated protein kinase (PRK1) and oxysterol-binding proteins (Skirpan et al., 2006), which could indicate that this complex forms a platform for signaling between the interior and exterior of the cell. Their potential influence on male gametophyte development and pollen viability is an interesting topic for further study.

NET3A localizes to the NE as well as to actin filaments within the cytoplasm. Perhaps it could form complexes with some of the known NE localized cytoskeleton interacting proteins (e.g., myosins and WIPs), assisting in the regulation of plant nuclear structure and function. NET3B, the remaining uncharacterized member of the NET3 family, expresses strongly in pollen and vascular tissue, where NET3C is also present. The NET3B/3C double mutant exhibits defects in pollen development suggesting

\section{References}

Amari, K., Di Donato, M., Dolja, V. V., and Heinlein, M. (2014). Myosins VIII and XI play distinct roles in reproduction and transport of tobacco mosaic virus. PLoS Pathog. 10:e1004448. doi: 10.1371/journal.ppat.1004448

Appenzeller-Herzog, C., and Hauri, H. P. (2006). The ER-Golgi intermediate compartment (ERGIC): in search of its identity and function. J. Cell Sci. 119, 2173-2183. doi: 10.1242/jcs.03019

Avisar, D., Abu-Abied, M., Belausov, E., Sadot, E., Hawes, C., and Sparkes, I. A. (2009). A comparative study of the involvement of 17 Arabidopsis myosin family members on the motility of Golgi and other organelles. Plant Physiol. 150, 700-709. doi: 10.1104/pp.109.136853

Avisar, D., Prokhnevsky, A. I., Makarova, K. S., Koonin, E. V., and Dolja, V. V. (2008a). Myosin XI-K is required for rapid trafficking of Golgi stacks, peroxisomes, and mitochondria in leaf cells of Nicotiana benthamiana. Plant Physiol. 146, 1098-1108. doi: 10.1104/pp.107.113647

Avisar, D., Prokhnevsky, A. I., and Dolja, V. V. (2008b). Class VIII myosins are required for plasmodesmatal localization of a Closterovirus Hsp70 homolog. J. Virol. 82, 2836-2843. doi: 10.1128/JVI.02246-07

Blanchoin, L., and Staiger, C. J. (2010). Plant formins: diverse isoforms and unique molecular mechanism. Biochim. Biophys. Acta 1803, 201-206. doi: 10.1016/j.bbamcr.2008.09.015

Boevink, P., Oparka, K., Santa Cruz, S., Martin, B., Betteridge, A., and Hawes, C. (1998). Stacks on tracks: the plant Golgi apparatus traffics on an actin/ER network. Plant J. 15, 441-447. doi: 10.1046/j.1365-313X.1998. 00208.x

Boutté, Y., and Moreau, P. (2014). Modulation of endomembranes morphodynamics in the secretory/retrograde pathways depends on lipid diversity. Curr. Opin. Plant Biol. 22, 22-29. doi: 10.1016/j.pbi.2014.08.004 that there is likely to be some functional redundancy between these two proteins (Wang et al., 2014).

NET4A localizes to the tonoplast, where it forms a characteristic NET protein "beads-on-a-string" localization pattern, the beads depicting potential membrane contact sites and the string as actin filaments (Deeks et al., 2012). In contrast to other vacuole membrane intrinsic proteins, the localization of NET4A does not show any obvious alteration in response to auxin stimuli (Lofke et al., 2015). NET4A is the first protein known to bind actin filaments at the tonoplast in plants. Two NET4 homologs are found in Arabidopsis, both of which interact with actin filaments but they have slightly different expression profiles. Based on their localization it is possible that NET4 is involved in maintaining tonoplast structure (Hawkins et al., 2014).

So far, our knowledge of the NET family is limited. However, the studies to date would indicate that at least a few members of the family are essential in establishing and maintaining links with different membrane systems. Their mode of action is unknown and future work will revolve around understanding their function in plant cell morphogenesis. The association of the actin cytoskeleton with membrane compartments is a general phenomenon in plant cells. Adaptor proteins at the site of the actin and membrane interface are essential, not only for regulating organelle dynamics and movement, but also for providing the structural integrity and specificity for various membrane organization/fusion events during plant development. Future studies will involve identifying the components of the NET-adaptor complexes, and their mechanism of action in different subcellular events.
Brandizzi, F., Snapp, E. L., Roberts, A. G., Lippincott-Schwartz, J., and Hawes, C. (2002). Membrane protein transport between the endoplasmic reticulum and the Golgi in tobacco leaves is energy dependent but cytoskeleton independent: evidence from selective photobleaching. Plant Cell 14, 1293-1309. doi: $10.1105 /$ tpc.001586

Cheung, A. Y., Niroomand, S., Zou, Y., and Wu, H. M. (2010). A transmembrane formin nucleates subapical actin assembly and controls tip-focused growth in pollen tubes. Proc. Natl. Acad. Sci. U.S.A. 107, 16390-16395. doi: 10.1073/pnas. 1008527107

Cheung, A. Y., and Wu, H. M. (2004). Overexpression of an Arabidopsis formin stimulates supernumerary actin cable formation from pollen tube cell membrane. Plant Cell 16, 257-269. doi: 10.1105/tpc.016550

Cvrckova, F. (2013). Formins and membranes: anchoring cortical actin to the cell wall and beyond. Front. Plant Sci. 4:436. doi: 10.3389/fpls.2013.00436

Debono, A., Yeats, T. H., Rose, J. K., Bird, D., Jetter, R., Kunst, L., et al. (2009). Arabidopsis LTPG is a glycosylphosphatidylinositol-anchored lipid transfer protein required for export of lipids to the plant surface. Plant Cell 21, 1230-1238. doi: 10.1105/tpc.108.064451

Deeks, M. J., Calcutt, J. R., Ingle, E. K., Hawkins, T. J., Chapman, S., Richardson, A. C., et al. (2012). A superfamily of actin-binding proteins at the actinmembrane nexus of higher plants. Curr. Biol. 22, 1595-1600. doi: 10.1016/j.cub. 2012.06.041

Deeks, M. J., and Hussey, P. J. (2005). Arp2/3 and SCAR: plants move to the fore Nat. Rev. Mol. Cell Biol. 6, 954-964. doi: 10.1038/nrm1765

Deeks, M. J., Cvrckova, F., Machesky, L. M., Mikitova, V., Ketelaar, T., Zarsky, V., et al. (2005). Arabidopsis group Ie formins localize to specific cell membrane domains, interact with actin-binding proteins and cause defects in cell expansion upon aberrant expression. New Phytol. 168, 529-540. doi: 10.1111/j.1469-8137. 2005.01582.x 
Deeks, M. J., Fendrych, M., Smertenko, A., Bell, K. S., Oparka, K., Cvrckova, F., et al. (2010). The plant formin AtFH4 interacts with both actin and microtubules, and contains a newly identified microtubule-binding domain. J. Cell Sci. 123, 1209-1215. doi: $10.1242 /$ jcs. 065557

Ding, Y., Robinson, D. G., and Jiang, L. (2012). Unconventional protein secretion (UPS) pathways in plants. Curr. Opin. Cell Biol. 29, 107-115. doi: 10.1016/j.ceb.2014.05.008

Dyachok, J., Shao, M. R., Vaughn, K., Bowling, A., Facette, M., Djakovic, S., et al. (2008). Plasma membrane-associated SCAR complex subunits promote cortical F-actin accumulation and normal growth characteristics in Arabidopsis roots. Mol. Plant 1, 990-1006. doi: 10.1093/mp/ssn059

Facette, M. R., Park, Y., Sutimantanapi, D., Luo, A., Cartwright, H. N., Yang, B., et al. (2015). The SCAR/WAVE complex polarizes PAN receptors and promotes division asymmetry in maize. Nat. Plants 1, 14024. doi: 10.1038/nplants. 2014.24

Favery, B., Chelysheva, L. A., Lebris, M., Jammes, F., Marmagne, A., De AlmeidaEngler, J., et al. (2004). Arabidopsis formin AtFH6 is a plasma membraneassociated protein upregulated in giant cells induced by parasitic nematodes. Plant Cell 16, 2529-2540. doi: 10.1105/tpc.104.024372

Feeney, M., Frigerio, L., Cui, Y., and Menassa, R. (2013). Following vegetative to embryonic cellular changes in leaves of Arabidopsis overexpressing LEAFY COTYLEDON2. Plant Physiol. 162, 1881-1896. doi: 10.1104/pp.113.220996

Fitzgibbon, J., Bell, K., King, E., and Oparka, K. (2010). Super-resolution imaging of plasmodesmata using three-dimensional structured illumination microscopy. Plant Physiol. 153, 1453-1463. doi: 10.1104/pp.110.157941

Golomb, L., Abu-Abied, M., Belausov, E., and Sadot, E. (2008). Different subcellular localizations and functions of Arabidopsis myosin VIII. BMC Plant Biol. 8:3. doi: 10.1186/1471-2229-8-3

Graumann, K., and Evans, D. E. (2011). Nuclear envelope dynamics during plant cell division suggest common mechanisms between kingdoms. Biochem. J. 435, 661-667. doi: 10.1042/BJ20101769

Graumann, K., Vanrobays, E., Tutois, S., Probst, A. V., Evans, D. E., and Tatout, C. (2014). Characterization of two distinct subfamilies of SUN-domain proteins in Arabidopsis and their interactions with the novel KASH-domain protein AtTIK. J. Exp. Bot. 65, 6499-6512. doi: 10.1093/jxb/eru368

Griffing, L. R., Gao, H. T., and Sparkes, I. (2014). ER network dynamics are differentially controlled by myosins XI-K, XI-C, XI-E, XI-I, XI-1, and XI-2. Front. Plant Sci. 5:218. doi: 10.3389/fpls.2014.00218

Hamada, T., Ueda, H., Kawase, T., and Hara-Nishimura, I. (2014). Microtubules contribute to tubule elongation and anchoring of endoplasmic reticulum, resulting in high network complexity in Arabidopsis. Plant Physiol. 166, 1869-1876. doi: 10.1104/pp.114.252320

Hanton, S. L., Matheson, L. A., Chatre, L., and Brandizzi, F. (2009). Dynamic organization of COPII coat proteins at endoplasmic reticulum export sites in plant cells. Plant J. 57, 963-974. doi: 10.1111/j.1365-313X.2008.03740.x

Hardham, A. R., Takemoto, D., and White, R. G. (2008). Rapid and dynamic subcellular reorganization following mechanical stimulation of Arabidopsis epidermal cells mimics responses to fungal and oomycete attack. BMC Plant Biol. 8:63. doi: 10.1186/1471-2229-8-63

Hashimoto, K., Igarashi, H., Mano, S., Nishimura, M., Shimmen, T., and Yokota, E. (2005). Peroxisomal localization of a myosin XI isoform in Arabidopsis thaliana. Plant Cell Physiol. 46, 782-789. doi: 10.1093/pcp/pci085

Hawes, C. (2005). Cell biology of the plant Golgi apparatus. New Phytol. 165, 29-44. doi: $10.1111 / j .1469-8137.2004 .01218 . x$

Hawkins, T. J., Deeks, M. J., Wang, P., and Hussey, P. J. (2014). The evolution of the actin binding NET superfamily. Front. Plant Sci. 5:254. doi: 10.3389/fpls.2014.00254

Higa, T., Suetsugu, N., Kong, S. G., and Wada, M. (2014). Actin-dependent plastid movement is required for motive force generation in directional nuclear movement in plants. Proc. Natl. Acad. Sci. U.S.A. 111, 4327-4331. doi: $10.1073 /$ pnas. 1317902111

Higaki, T., Kutsuna, N., Okubo, E., Sano, T., and Hasezawa, S. (2006). Actin microfilaments regulate vacuolar structures and dynamics: dual observation of actin microfilaments and vacuolar membrane in living tobacco BY-2 Cells. Plant Cell Physiol. 47, 839-852. doi: 10.1093/pcp/pcj056

Hunter, P. R., Craddock, C. P., Di Benedetto, S., Roberts, L. M., and Frigerio, L. (2007). Fluorescent reporter proteins for the tonoplast and the vacuolar lumen identify a single vacuolar compartment in Arabidopsis cells. Plant Physiol. 145, 1371-1382. doi: $10.1104 /$ pp.107.103945
Hussey, P. J., Allwood, E. G., and Smertenko, A. P. (2002). Actin-binding proteins in the Arabidopsis genome database: properties of functionally distinct plant actin-depolymerizing factors/cofilins. Philos. Trans. R. Soc. Lond. B Biol. Sci. 357, 791-798. doi: 10.1098/rstb.2002.1086

Hussey, P. J., Ketelaar, T., and Deeks, M. J. (2006). Control of the actin cytoskeleton in plant cell growth. Аnnu. Rev. Plant Biol. 57, 109-125. doi: 10.1146/annurev.arplant.57.032905.105206

Jimenez-Lopez, J. C., Wang, X., Kotchoni, S. O., Huang, S., Szymanski, D. B., and Staiger, C. J. (2014). Heterodimeric capping protein from Arabidopsis is a membrane-associated, actin-binding protein. Plant Physiol. 166, 1312-1328. doi: 10.1104/pp.114.242487

Jurgens, G. (2004). Membrane trafficking in plants. Annu. Rev. Cell Dev. Biol. 20, 481-504. doi: 10.1146/annurev.cellbio.20.082503.103057

Kadota, A., Yamada, N., Suetsugu, N., Hirose, M., Saito, C., Shoda, K., et al. (2009). Short actin-based mechanism for light-directed chloroplast movement in Arabidopsis. Proc. Natl. Acad. Sci. U.S.A. 106, 13106-13111. doi: 10.1073/pnas.0906250106

Kim, H., Park, M., Kim, S. J., and Hwang, I. (2005). Actin filaments play a critical role in vacuolar trafficking at the Golgi complex in plant cells. Plant Cell 17, 888-902. doi: $10.1105 /$ tpc. 104.028829

Kriechbaumer, V., Wang, P., Hawes, C., and Abell, B. M. (2012). Alternative splicing of the auxin biosynthesis gene YUCCA4 determines its subcellular compartmentation. Plant J. 70, 292-302. doi: 10.1111/j.1365-313X.2011. 04866.x

Lanza, M., Garcia-Ponce, B., Castrillo, G., Catarecha, P., Sauer, M., RodriguezSerrano, M., et al. (2012). Role of actin cytoskeleton in brassinosteroid signaling and in its integration with the auxin response in plants. Dev. Cell 22, 1275-1285. doi: 10.1016/j.devcel.2012.04.008

Li, G., Liang, W., Zhang, X., Ren, H., Hu, J., Bennett, M. J., et al. (2014). Rice actin-binding protein RMD is a key link in the auxin-actin regulatory loop that controls cell growth. Proc. Natl. Acad. Sci. U.S.A. 111, 10377-10382. doi: 10.1073/pnas.1401680111

Li, J., Henty-Ridilla, J. L., Huang, S., Wang, X., Blanchoin, L., and Staiger, C. J. (2012). Capping protein modulates the dynamic behavior of actin filaments in response to phosphatidic acid in Arabidopsis. Plant Cell 24, 3742-3754. doi: $10.1105 /$ tpc. 112.103945

Li, L. J., Ren, F., Gao, X. Q., Wei, P. C., and Wang, X. C. (2013). The reorganization of actin filaments is required for vacuolar fusion of guard cells during stomatal opening in Arabidopsis. Plant Cell Environ. 36, 484-497. doi: 10.1111/j.13653040.2012.02592.x

Li, Y., Shen, Y., Cai, C., Zhong, C., Zhu, L., Yuan, M., et al. (2010). The type II Arabidopsis formin14 interacts with microtubules and microfilaments to regulate cell division. Plant Cell 22, 2710-2726. doi: 10.1105/tpc.110.075507

Lofke, C., Dunser, K., Scheuring, D., and Kleine-Vehn, J. (2015). Auxin regulates SNARE-dependent vacuolar morphology restricting cell size. Elife 4: e05868. doi: 10.7554/eLife.05868

Martiniére, A., Bassil, E., Jublanc, E., Alcon, C., Reguera, M., Sentenac, H., et al. (2013). In vivo intracellular $\mathrm{pH}$ measurements in tobacco and Arabidopsis reveal an unexpected $\mathrm{pH}$ gradient in the endomembrane system. Plant Cell 25, 4028-4043. doi: 10.1105/tpc.113.116897

Martiniére, A., Gayral, P., Hawes, C., and Runions, J. (2011). Building bridges: formin 1 of Arabidopsis forms a connection between the cell wall and the actin cytoskeleton. Plant J. 66, 354-365. doi: 10.1111/j.1365-313X.2011.04497.x

Mathur, J., Mathur, N., Kirik, V., Kernebeck, B., Srinivas, B. P., and Hulskamp, M. (2003). Arabidopsis CROOKED encodes for the smallest subunit of the ARP2/3 complex and controls cell shape by region specific fine F-actin formation. Development 130, 3137-3146. doi: 10.1242/dev.00549

Meier, I. (2007). Composition of the plant nuclear envelope: theme and variations. J. Exp. Bot. 58, 27-34. doi: 10.1093/jxb/erl009

Olbrich, A., Hillmer, S., Hinz, G., Oliviusson, P., and Robinson, D. G. (2007). Newly formed vacuoles in root meristems of barley and pea seedlings have characteristics of both protein storage and lytic vacuoles. Plant Physiol. 145, 1383-1394. doi: 10.1104/pp.107.108985

Pena, E. J., and Heinlein, M. (2013). Cortical microtubule-associated ER sites: organization centers of cell polarity and communication. Curr. Opin. Plant Biol. 16, 764-773. doi: 10.1016/j.pbi.2013.10.002

Peremyslov, V. V., Klocko, A. L., Fowler, J. E., and Dolja, V. V. (2012). Arabidopsis myosin XI-K localizes to the motile endomembrane vesicles associated with F-actin. Front. Plant Sci. 3:184. doi: 10.3389/fpls.2012.00184 
Peremyslov, V. V., Prokhnevsky, A. I., Avisar, D., and Dolja, V. V. (2008). Two class XI myosins function in organelle trafficking and root hair development in Arabidopsis. Plant Physiol. 146, 1109-1116. doi: 10.1104/pp.107.113654

Peremyslov, V. V., Prokhnevsky, A. I., and Dolja, V. V. (2010). Class XI myosins are required for development, cell expansion, and F-Actin organization in Arabidopsis. Plant Cell 22, 1883-1897. doi: 10.1105/tpc.110. 076315

Pleskot, R., Li, J., Zarsky, V., Potocky, M., and Staiger, C. J. (2013). Regulation of cytoskeletal dynamics by phospholipase D and phosphatidic acid. Trends Plant Sci. 18, 496-504. doi: 10.1016/j.tplants.2013.04.005

Pleskot, R., Potocky, M., Pejchar, P., Linek, J., Bezvoda, R., Martinec, J., et al. (2010). Mutual regulation of plant phospholipase $\mathrm{D}$ and the actin cytoskeleton. Plant J. 62, 494-507. doi: 10.1111/j.1365-313X.2010.04168.x

Radford, J. E., and White, R. G. (1998). Localization of a myosin-like protein to plasmodesmata. Plant J. 14, 743-750. doi: 10.1046/j.1365-313x.1998. 00162.x

Reichelt, S., Knight, A. E., Hodge, T. P., Baluska, F., Samaj, J., Volkmann, D., et al. (1999). Characterization of the unconventional myosin VIII in plant cells and its localization at the post-cytokinetic cell wall. Plant J. 19, 555-567. doi: 10.1046/j.1365-313X.1999.00553.x

Robinson, D. G., Brandizzi, F., Hawes, C., and Nakano, A. (2015). Vesicles versus Tubes: is ER-Golgi transport in plants fundamentally different to other eukaryotes ? Plant Physiol. doi: 10.1104/pp.15.00124 [Epub ahead of print].

Saint-Jore, C. M., Evins, J., Batoko, H., Brandizzi, F., Moore, I., and Hawes, C. (2002). Redistribution of membrane proteins between the Golgi apparatus and endoplasmic reticulum in plants is reversible and not dependent on cytoskeletal networks. Plant J. 29, 661-678. doi: 10.1046/j.0960-7412.2002. 01252.x

Sampathkumar, A., Gutierrez, R., Mcfarlane, H. E., Bringmann, M., Lindeboom, J., Emons, A. M., et al. (2013). Patterning and lifetime of plasma membranelocalized cellulose synthase is dependent on actin organization in Arabidopsis interphase cells. Plant Physiol. 162, 675-688. doi: 10.1104/pp.113.215277

Sattarzadeh, A., Krahmer, J., Germain, A. D., and Hanson, M. R. (2009). A myosin XI tail domain homologous to the yeast myosin vacuole-binding domain interacts with plastids and stromules in Nicotiana benthamiana. Mol. Plant 2, 1351-1358. doi: 10.1093/mp/ssp094

Sattarzadeh, A., Schmelzer, E., and Hanson, M. R. (2013). Arabidopsis myosin $\mathrm{XI}$ sub-domains homologous to the yeast myo2p organelle inheritance subdomain target subcellular structures in plant cells. Front. Plant Sci. 4:407. doi: 10.3389/fpls.2013.00407

Schumacher, K. (2014). pH in the plant endomembrane system-an import and export business. Curr. Opin. Plant Biol. 22, 71-76. doi: 10.1016/j.pbi.2014.09. 005

Sheahan, M. B., Rose, R. J., and Mccurdy, D. W. (2007). Actin-filament-dependent remodeling of the vacuole in cultured mesophyll protoplasts. Protoplasma 230, 141-152. doi: 10.1007/s00709-006-0236-5

Skirpan, A. L., Dowd, P. E., Sijacic, P., Jaworski, C. J., Gilroy, S., and Kao, T. H. (2006). Identification and characterization of PiORP1, a Petunia oxysterolbinding-protein related protein involved in receptor-kinase mediated signaling in pollen, and analysis of the ORP gene family in Arabidopsis. Plant Mol. Biol. 61, 553-565. doi: 10.1007/s11103-006-0030-y

Sparkes, I., Hawes, C., and Frigerio, L. (2011). FrontiERs: movers and shapers of the higher plant cortical endoplasmic reticulum. Curr. Opin. Plant Biol. 14, 658-665. doi: 10.1016/j.pbi.2011.07.006

Sparkes, I., Runions, J., Hawes, C., and Griffing, L. (2009a). Movement and remodeling of the endoplasmic reticulum in nondividing cells of tobacco leaves. Plant Cell 21, 3937-3949. doi: 10.1105/tpc.109.072249

Sparkes, I. A., Ketelaar, T., De Ruijter, N. C., and Hawes, C. (2009b). Grab a Golgi: laser trapping of Golgi bodies reveals in vivo interactions with the endoplasmic reticulum. Traffic 10, 567-571. doi: 10.1111/j.1600-0854.2009.00891.x

Sparkes, I. A., Teanby, N. A., and Hawes, C. (2008). Truncated myosin XI tail fusions inhibit peroxisome, Golgi, and mitochondrial movement in tobacco leaf epidermal cells: a genetic tool for the next generation. J. Exp. Bot. 59, 2499-2512. doi: 10.1093/jxb/ern114

Suetsugu, N., Yamada, N., Kagawa, T., Yonekura, H., Uyeda, T. Q., Kadota, A., et al. (2010). Two kinesin-like proteins mediate actin-based chloroplast movement in Arabidopsis thaliana. Proc. Natl. Acad. Sci. U.S.A. 107, 8860-8865. doi: $10.1073 /$ pnas.0912773107
Sun, T., Li, S., and Ren, H. (2013). Profilin as a regulator of the membraneactin cytoskeleton interface in plant cells. Front. Plant Sci. 4:512. doi: 10.3389/fpls.2013.00512

Surpin, M., and Raikhel, N. (2004). Traffic jams affect plant development and signal transduction. Nat. Rev. Mol. Cell Biol. 5, 100-109. doi: 10.1038/nrm1311

Tamura, K., Iwabuchi, K., Fukao, Y., Kondo, M., Okamoto, K., Ueda, H., et al. (2013). Myosin XI-i links the nuclear membrane to the cytoskeleton to control nuclear movement and shape in Arabidopsis. Curr. Biol. 23, 1776-1781. doi: 10.1016/j.cub.2013.07.035

Tilsner, J., Linnik, O., Louveaux, M., Roberts, I. M., Chapman, S. N., and Oparka, K. J. (2013). Replication and trafficking of a plant virus are coupled at the entrances of plasmodesmata. J. Cell Biol. 201, 981-995. doi: 10.1083/jcb.201304003

Ueda, H., Yokota, E., Kutsuna, N., Shimada, T., Tamura, K., Shimmen, T., et al. (2010). Myosin-dependent endoplasmic reticulum motility and F-actin organization in plant cells. Proc. Natl. Acad. Sci. U.S.A. 107, 6894-6899. doi: 10.1073/pnas.0911482107

Uhrig, J. F., Mutondo, M., Zimmermann, I., Deeks, M. J., Machesky, L. M., Thomas, P., et al. (2007). The role of Arabidopsis SCAR genes in ARP2-ARP3-dependent cell morphogenesis. Development 134, 967-977. doi: 10.1242/dev.02792

Van Gisbergen, P. A., Li, M., Wu, S. Z., and Bezanilla, M. (2012). Class II formin targeting to the cell cortex by binding $\mathrm{PI}(3,5) \mathrm{P}(2)$ is essential for polarized growth. J. Cell Biol. 198, 235-250. doi: 10.1083/jcb.201112085

Vedrenne, C., Klopfenstein, D. R., and Hauri, H. P. (2005). Phosphorylation controls CLIMP-63-mediated anchoring of the endoplasmic reticulum to microtubules. Mol. Biol. Cell 16, 1928-1937. doi: 10.1091/mbc.E04-07-0554

Vedrenne, C., and Hauri, H. P. (2006). Morphogenesis of the endoplasmic reticulum: beyond active membrane expansion. Traffic 7, 639-646. doi: 10.1111/j.1600-0854.2006.00419.x

Vitale, A., and Denecke, J. (1999). The endoplasmic reticulum-gateway of the secretory pathway. Plant Cell 11, 615-628. doi: 10.2307/3870888

Wang, P., Hawkins, T. J., Richardson, C., Cummins, I., Deeks, M. J., Sparkes, I., et al. (2014). The plant cytoskeleton, NET3C, and VAP27 mediate the link between the plasma membrane and endoplasmic reticulum. Curr. Biol. 24, 1397-1405. doi: 10.1016/j.cub.2014.05.003

Wang, P., Hummel, E., Osterrieder, A., Meyer, A. J., Frigerio, L., Sparkes, I., et al. (2011). KMS1 and KMS2, two plant endoplasmic reticulum proteins involved in the early secretory pathway. Plant J. 66, 613-628. doi: 10.1111/j.1365313X.2011.04522.X

Watson, P., Forster, R., Palmer, K. J., Pepperkok, R., and Stephens, D. J. (2005). Coupling of ER exit to microtubules through direct interaction of COPII with dynactin. Nat. Cell Biol. 7, 48-55. doi: 10.1038/ncb1206

Xue, X. H., Guo, C. Q., Du, F., Lu, Q. L., Zhang, C. M., and Ren, H. Y. (2011). AtFH8 is involved in root development under effect of low-dose latrunculin B in dividing cells. Mol. Plant 4, 264-278. doi: 10.1093/mp/ssq085

Yokota, E., Ueda, H., Hashimoto, K., Orii, H., Shimada, T., Hara-Nishimura, I., et al. (2011). Myosin XI-dependent formation of tubular structures from endoplasmic reticulum isolated from tobacco cultured BY-2 cells. Plant Physiol. 156, 129-143. doi: 10.1104/pp.111.175018

Yokota, E., Ueda, S., Tamura, K., Orii, H., Uchi, S., Sonobe, S., et al. (2009). An isoform of myosin XI is responsible for the translocation of endoplasmic reticulum in tobacco cultured BY-2 cells. J. Exp. Bot. 60, 197-212. doi: $10.1093 /$ jxb/ern280

Zhang, C., Kotchoni, S. O., Samuels, A. L., and Szymanski, D. B. (2010). SPIKE1 signals originate from and assemble specialized domains of the endoplasmic reticulum. Curr. Biol. 20, 2144-2149. doi: 10.1016/j.cub.2010.11.016

Zhang, C., Mallery, E., Reagan, S., Boyko, V. P., Kotchoni, S. O., and Szymanski, D. B. (2013a). The endoplasmic reticulum is a reservoir for WAVE/SCAR regulatory complex signaling in the Arabidopsis leaf. Plant Physiol. 162, 689-706. doi: $10.1104 /$ pp.113.217422

Zhang, C., Mallery, E. L., and Szymanski, D. B. (2013b). ARP2/3 localization in Arabidopsis leaf pavement cells: a diversity of intracellular pools and cytoskeletal interactions. Front. Plant Sci. 4:238. doi: 10.3389/fpls.2013.00238

Zhang, Q., Lin, F., Mao, T., Nie, J., Yan, M., Yuan, M., et al. (2012). Phosphatidic acid regulates microtubule organization by interacting with MAP65-1 in response to salt stress in Arabidopsis. Plant Cell 24, 4555-4576. doi: 10.1105/tpc.112.104182

Zhang, Z., Zhang, Y., Tan, H., Wang, Y., Li, G., Liang, W., et al. (2011). RICE MORPHOLOGY DETERMINANT encodes the type II formin FH5 and regulates rice morphogenesis. Plant Cell 23, 681-700. doi: 10.1105/tpc.110. 081349 
Zhou, X., Graumann, K., Evans, D. E., and Meier, I. (2011). Novel plant SUN-KASH bridges are involved in RanGAP anchoring and nuclear shape determination. J. Cell Biol. 196, 203-211. doi: 10.1083/jcb.201108098

Zhou, X., Graumann, K., Wirthmueller, L., Jones, J. D., and Meier, I. (2014). Identification of unique SUN-interacting nuclear envelope proteins with diverse functions in plants. J. Cell Biol. 205, 677-692. doi: 10.1083/jcb.201401138

Zhou, X., and Meier, I. (2014). Efficient plant male fertility depends on vegetative nuclear movement mediated by two families of plant outer nuclear membrane proteins. Proc. Natl. Acad. Sci. U.S.A. 111, 11900-11905. doi: $10.1073 /$ pnas.1323104111
Conflict of Interest Statement: The authors declare that the research was conducted in the absence of any commercial or financial relationships that could be construed as a potential conflict of interest.

Copyright (C) 2015 Wang and Hussey. This is an open-access article distributed under the terms of the Creative Commons Attribution License (CC BY). The use, distribution or reproduction in other forums is permitted, provided the original author(s) or licensor are credited and that the original publication in this journal is cited, in accordance with accepted academic practice. No use, distribution or reproduction is permitted which does not comply with these terms. 